\title{
Ekososiaalinen sivistys herättää luottamusta tulevaisuuteen
}

\begin{abstract}
$y$
Ihmiskunnan tulee omaksua uudenlainen sivistyskäsitys, jossa hyvää elämää tavoitellaan yhden maapallon rajoissa. Ekososiaalisesti sivistynyt

ihminen tunnistaa keskinäisriippuvuuksia ekologisen, sosiaalisen ja taloudellisen todellisuuden välillä. Pohjimmiltaan ekososiaalinen sivistys on myös talouden toimintaedellytysten varmistaja.
\end{abstract}

SUOMALAISESSA VALTAVIRTA-AJATTELUSSA myönteiseksi kehitykseksi mielletään kulutuksen ja markkinoiden kasvu. Elämäntapamme edellyttämä luonnonvarojen määrä on maailman 7. suurinta siinä missä ruotsalaisten 25. ja norjalaisten 26. suurinta maailmassa (Dittrich ym. 2012). Myös suomalaisen kuluttamisen hiilidioksidipäästöt ovat ruotsalaisia ja norjalaisia suuremmat - sijaluvulla 9. koko maailmassa (Caldeira \& Davies 2010). Asukasta kohden kuluvien luonnonvarojen vuotuinen määrä ylittää Suomessa jo yhdysvaltalaisten kulutuksen (Wiedmann 2013).

Hyvinvointiajattelun avartamista tarvitaan, sillä maapallo on rajallinen (Rees 2014, 196). Yhteinen ilmakehä ja luonnonvarat jaetaan yhä useamman ihmisen kesken. Nykymuotoisen talouden perusta uhkaa murentua ylittäessämme rajallisen planeettamme kantokyvyn rajat. Lisäksi kehityksestä koituvat hyödyt ja haitat jakautuvat epätasaisesti. Eriarvosta seuraava jännitteisyys vähentää yhteiskuntien eheyttä ja kansalaisten välistä luottamusta. (Ehrlich, Kareiva \& Daily 2012; The Royal Society 2012.)

Ennakoimme tulevaa hahmottelemalla näköaloja sellaiseen sivistykseen, joka ilmenee kestävämpänä elämäntapana, yhteiskuntana ja kulttuurina. Kyse ei ole ennustamisesta vaan mahdollisuuksien muotoilusta (Miles ym. 2003). Liitymme kansainväliseen ja kotimaiseen keskusteluun kehityksen ja sivistyksen luonteesta siinä tarkoituksessa, että toimeliaisuus tulevaisuuteen valmistautumisessa monipuolistuisi. 
Tarkasteluamme ohjaa suuri kysymys siitä, millainen sivistyskäsitys voisi säilyttää nykyiset ihmisten toimintamahdollisuudet ja tukisi samalla niiden laajentumista siten, että tulevilla sukupolvilla olisi samat mahdollisuudet ja vapaudet kuin meillä - tai vielä enemmän (Sen 2009, 251-252). Kiinnostuksemme kohteena on sellaisen sivistyskäsityksen muotoilu, jonka suuntaamana olisi mahdollista rakentaa luottamusta herättävää tulevaisuutta Suomessa, joka on osa keskinäisriippuvaista globaalia toimintaympäristöä ja planetaarista kokonaisuutta.

Toivomme, että lukija testaa argumentointimme pitävyyttä aktiivisesti. Emme vertaile erilaisia argumentaatiopolkuja vaan luomme yhden mahdollisimman ehjän ja konkreettisen kuvauksen sellaisen sivistyksen luonteesta, josta tulevat sukupolvet voisivat olla ylpeitä.

Jotta tulevaisuuden toivo säilyisi, tarvitsemme kenties enemmän kuin koskaan aiemmin keskustelua yhteiskunnallisen neuvokkuuden generoimisessa ja hyvinvoinnin tekijöiden tärkeysjärjestyksen ymmärtämisessä (Bardy 2015; Salonen 2014; 2015).

\section{EKOSOSIAALISEN SIVISTYSKÄSITYKSEN PERUSTA}

\section{Vallalla olevan olemassaolemisen ihanteen kritiikki}

Sivistys karttuu elinikäisessä oppimisessa. Suomen kielessä sivistys viittaa yksilön henkiseen kehittyneisyyteen, olemukseen, käytöstapoihin tai kansalliseen kulttuuriin (Kokko 2010, 7). Hyvän elämän tavoittelun tavat ja sivistys ovat siis kytköksissä toisiinsa (Ojanen 2008). Sivistykseen liitetään yleensä avarakatseisuus ja taito asettua toisen ihmisen asemaan. Sivistyksen katsotaan myös edellyttävän kykyä muodostaa poikkitiedollinen kokonaiskäsitys ympäröivästä todellisuudesta. Sille on ominaista sellaisten uusien näköalojen avautuminen elämään, jotka vahvistavat tuntua elämän merkityksellisyydestä.

Hyvän elämän tavoittelussa on viime vuosikymmeninä korostunut vaurauden tavoittelu. Yh- teiskunnan edistymistä on mitattu kapea-alaisesti bruttokansantuotteen avulla. Vähäiselle huomiolle on jäänyt se, että tuotannon ja kulutuksen määrää mittaava bruttokansantuote on samalla yksi parhaimmista tilastollisista indikaattoreista hyvinvointia rapauttaville asioille kuten liikenneruuhkille, ympäristön saastumiselle, stressille, luonnon monimuotoisuuden köyhtymiselle ja luonnon ekosysteemien ehtymiselle.

Hyvinvointimallimme ydintabu on talouden ja kulutuksen jatkuvan kasvun prinsiippi. Sen taustatabu on kestämättömäksi kulutukseksi vääristynyt luontosuhde. Näistä seuraavia oheistabuja ovat muun muassa aineellisen vaurauden ylikorostuminen, eriarvoisuuden kasvun hyväksyminen sekä epätasapaino kauppiasmoraalin ja huolenpitomoraalin välillä. Niistä kumpaakin tarvitaan: kauppiasmoraalin tarkoitus on tuottaa voittoa, ja huolenpitomoraalin tehtävänä on vaalia sitä, mitä ei voi panna kaupan (Bardy \& Parrukoski 2010, 100-101, 187-189).

Teollisen aikakauden aikana vapautta on korostettu, mutta kokonaisvaltainen vastuu on usein ohitettu (Ehrlich \& Ehrlich 2013). Kulutuskeskeisessä kilpailutaloudessa mielihyvä on irronnut moraaliselta perustaltaan talouden liikevoimaksi. Tätä vahvistaa hyve- ja velvollisuusetiikasta irtautuminen. Moraalikasvatuksesta luopuminen merkitsee periksiantamista haluamisen ylivallalle (Värri 2011). Nykyään "koulutusjärjestelmiä ollaan muokkaamassa kaikkialla maailmassa lähemmäs talouskasvumallia” (Nussbaum 2011, 39). Kehityksen suuntana on kasvatuksen redusoituminen pelkäksi talouden välineeksi (Värri 2011, 32).

Yhteiskunnan läpäisevällä markkinaehtoistumisella on monialaisia vaikutuksia. Hyötyajattelun laajentuessa elämä uhkaa köyhentyä. Yhteydet itseen, muihin ihmisiin, yhteiskuntaan, luontoon ja menneisyyteen välineellistyvät. Samalla merkityksettömyyden, tarkoituksettomuuden ja arvottomuuden kokemukset yleistyvät (Benzer 2011; Taylor 1995, 86-87). Ekonomisoitunut käsitys ihmisestä ja maa- 
ilmasta saattaa ohjata ajattelemaan, että yhteiskunnan uhkan muodostavat tyytyväiset kansalaiset, jotka eivät halua jatkuvasti lisätä kulutustaan, vaan tunnistavat, minkä verran materiaalista hyvää heille riittää.

Materiaalisen vaurauden kapea-alainen ihannointi taannuttaa ihmiskuntaa (Ojanen 2008). Kansalaisuuden merkitys uhkaa kaventua kuluttajuudeksi (Pulkki 2010). Vaikka vuosina 1966 2008 Suomen bruttokansantuote kolminkertaistui, suomalaisten kokema tyytyväisyys elämään ei lisääntynyt (Vaarama ym. 2010,13). Globaali eettinen haaste kulminoituu siihen, että ennen näkemättömästä vauraudesta huolimatta kasvu Suomessa on yhä useammin yhteydessä ihmisoikeusrikkomuksiin ja ekologiseen katastrofiin toisaalla (Eskelinen 2011; Max-Neef2010, 203-204).

\section{Elämää ylläpitävien tekijöiden tärkeysjärjestys}

Muotoilemamme ekososiaalinen sivistyskäsitys asemoituu sen varaan, mikä on hyvän elämän kannalta luovuttamatonta. Talouden selkäranka murtuu, jos elämän edellytyksiä turvaavat ekosysteemit turmeltuvat. Esimerkiksi ravinnontuotanto edellyttää maaperän uusiutumista ja suotuisaa ilmastoa. Talouden kehitystä ei nykyään enää estä teknologian puute vaan yhä useammin raaka-aineiden vähentyminen, kuten hupenevat kalastot, häviävät metsät ja laskeva pohjavesi. Luonnon ilmaiseksi tarjoamia ekosysteemipalveluja - kuten kasvien pölytyksiä, ilman puhdistusta ja kalaston uusiutumista - on jokseenkin mahdoton korvata ihmisvoimin (Randers 2012).

Tämän vuoksi ekososiaalisen sivistyskäsityksen mukaisen maailmanhahmottamisen hierarkia on seuraava (Salonen 2014; 2015):

1. Ekologisten kysymysten ensisijaisuus. Elämän edellytysten turvaaminen tuleville sukupolville on tärkein poliittisen päätöksenteon ja nykysukupolven ihmisten elämäntapojen kriteeri. Käytännössä kyse on hengityskelpoisesta ilmasta ja juomakelpoisesta vedestä; kasvien pölytysten turvaamisesta ja maaperän hedelmällisyyden säilymisen varmistamisesta; ilmaston vakaudesta ja maa-alueiden asuinkelpoisuuden säilymisestä sekä luonnonvarojen kestävästä käytöstä.

2. Ihmisoikeuksien luovuttamattomuus. Arvokkaan elämän mahdollisuuksien puolustaminen pelkästään ihmisyyden perusteella määrittyvänä periaatteena on toiseksi tärkein poliittisen päätöksenteon ja nykysukupolven ihmisten elämäntapoihin liittyvä kriteeri.

3. Vakaan talouden vaaliminen. Vakaan talouden vaaliminen on kolmanneksi tärkein ihmisen toiminnan kriteeri, jotta rajallisen maapallon resurssit voitaisiin jakaa täyttyvällä maapallolla mahdollisimman tehokkaasti ja varmistaa kaikkien ihmisten perustarpeiden tyydyttyminen.

Planetaaristen rajojen perustavuuden tunnistaminen ja hyväksyminen on olennaisinta, jotta inhimillinen elämä voisi jatkua. Ilman ekologista perustaa sosiaalista elämää ei voi olla olemassa (Adger 2000, 350). Ja ilman yhteisöjä ja yhteiskuntia ei voi olla sosiaalisia toimintoja, kuten taloutta. Talous on luonnon voimavaroihin ja ihmisen panoksiin perustuva ekososiaalinen prosessi. Sen perimmäisenä tehtävänä on turvata mahdollisuudet perustarpeiden tyydyttämiseen kaikille ihmisille (Max-Neef 2010, 205). Ekososiaalinen sivistys on pohjimmiltaan myös talouden toimintaedellytysten varmistaja.

Vallalla oleva markkinaehtoinen sivistyskäsitys on hierarkialtaan päinvastainen. Jos lyhyen aikavälin talouskasvua pidetään kaikkein tärkeimpänä asiana, saatetaan joutua uhraamaan elämän edellytysten säilyminen ja ihmisoikeudet. Halvasta hinnasta muodostuu tärkeämpi kriteeri kuin tuotannon ekologisesta ja sosiaalisesta vastuullisuudesta. Ihmisoikeudet eivät toteudu jokapäiväisessä elämässämme esimerkiksi vaatteiden, kaakaon, energiatuotannon ja teknologiatuotteiden tuotevalmistusketjuissa (Bureau of International Labor Affairs 2014). Kvartaaliperiaatteella toimiva talous ei kykene neuvomaan, kuinka turvata hyvän elämän edellytyksiä ja 
tulevien sukupolvien mahdollisuuksia (Daly 2010; Keskuskauppakamari 2012; Reardon 2012). Lyhytnäköinen voittojen tavoittelu kääntyy pitkällä aikavälillä ihmistä vastaan.

\section{Elämää ylläpitävien elementtien keskinäisriippuvuus}

Keskinäisriippuvuudet ilmenevät erilaisina yhteen kietoutumina, ketjureaktioina tai kiertokulkuina. Talous on vuorovaikutusta luonnon kanssa ja se tapahtuu sosiokulttuurisissa suhteissa. Inhimillisen toimeliaisuuden useimmat muodot sijoittuvat ekologian, talouden ja sosiaalisen risteyskohtiin. Siiloutunut käsitys todellisuudesta saattaa johtaa tulkintoihin, jotka eivät kestä kriittistä tarkastelua. Tämä on seurausta ajattelun pirstaloitumisesta, segmentoitumisesta tai fragmentoitumisesta, jolloin eri asioiden ja ilmiöiden väliset yhteydet vaikuttavat katkenneilta kapea-alaiseksi muuttuneen ajattelun vuoksi. Voidaan vaikkapa ajatella, että puhtaaseen veteen liittyvät kysymykset eivät ole suomalaisille tärkeitä, koska Suomessa vettä riittää. Tosiasiassa globaalin talouden vuoksi keskivertosuomalaisen kansalaisen kuluttamasta vedestä 47 prosenttia kuluu ulkomailla - suuri osa alueilla, joissa puhtaan veden saatavuus on uhattuna (Nikula 2012).

Keskinäisriippuvuuksien tunnistamattomuudesta seuraa epätaloudellista taloutta. Esimerkiksi fossiilisen energiasektorin voittoja tavoiteltaessa jää helposti huomiotta, että fossiilisen energian käytön kiihdyttämästä ilmastonmuutoksesta on seurauksena voitot nieleviä haittoja (Braconier ym. 2014). Tällainen markkinavirhe lisää epäluottamusta markkinoiden toimintaa kohtaan (Executive Office of the President of the United States 2014; OECD 2012). Pelkästään Itä-Siperian alueen meren pinnan alla olevan ikiroudan sulamisen vuoksi vapautuvan metaanin aiheuttamien haittojen kustannukset ovat lähes vuoden 2012 maailmantalouden suuruiset (Whiteman ym. 2013).

Keskinäisriippuvuuksiin perustuvalla maapallolla systeemiajattelu on avainasemassa (Hirvilammi
\& Helne 2014; Helne ym. 2012; 2014). Systeemiajattelun merkitystä havainnollistaa ruoka. Sitä tuotetaan, kokataan, syödään ja lopulta se ulostetaan. Ruoan kiertokulku on yhteydessä maahan, ilmaan ja veteen. Ruoka on kulttuurinen tuote, sillä muokattua luontoa tuodaan ruokapöytään. Ravinnoksi käytettynä tai hävikkinä se palautetaan takaisin luontoon. Ruoka on paikallinen ja globaali ilmiö. Täällä päin maailmaa syömme liikaa, mutta kehittyvissä maissa ruokaa saattaa olla niukasti. Nälänhätä uhkaa etenkin siellä, missä maata on otettu toisella puolella maapalloa asuvien autoilijoiden biopolttoaineen tuotantoon. Välittömät taloudelliset edut syrjäyttävät sosiaalisen, kulttuurisen ja ekologisen kestävyyden. (Bardy 2012a.) Tällainen toiminta osoittaa lyhytnäköistä itsekkyyttä.

Mikään maa ei pysty saavuttamaan kestävää yhteiskuntaa yksin. Esimerkiksi suomalaisten hiilidioksidipäästöistä kolmannes syntyy ulkomailla, sillä Aasia on nykyinen teollisuusalueemme (Caldeira \& Davies 2010). Paikallisen, globaalin ja tulevaisuuteen ulottuvan näkökulman yhdistäminen haastaa myös politiikan. Tänään ilmakehään vapautettu hiilidioksidi kiihdyttää ihmisen aiheuttamaa ilmastonmuutosta vielä vuosikymmenten ajan ja lisää etenkin hauraissa maissa asuvien ihmisten haavoittuvaisuutta esimerkiksi meren pinnan jo väistämättömän 3-4 metrin nousun vuoksi (Joughin ym. 2014; Rignot ym. 2014). Sen seurauksena ilmastopakolaisuus kasvaa, kun ihmisten kotiseudut muuttuvat asuinkelvottomiksi.

Ekologisten ja sosiaalisten kysymysten yhteistarkastelu sekä elämää ylläpitävien tekijöiden tärkeysjärjestyksen sisäistäminen muodostavat ekososiaalisen sivistyksen perustan. Siinä ihmisen tekemät todellisuuden tulkinnat edustavat mahdollisimman todenmukaisesti sitä monimutkaista maailmaa, jossa hän elää. Huomion kohteina ovat kestävyyttä ja elinvoimaisuutta edistävien ja heikentävien tekijöiden väliset syyseuraussuhteet. Entistä kokonaisvaltaisempi ja täydempi kokemus olevaisesta kehittyy oppimisprosessissa, jossa jatkuvasti anne- 
taan kokemuksille uusia merkityksiä ja katsotaan niitä uusista näkökulmista, koetellaan niitä. Kokemusjatkumon turvaaminen on tähdellistä. Pohtiva ihminen luottaa siihen, että hänen kokemuksensa ovat hänen toimintansa kehittämisen lähtökohta. (Alhanen 2013.)

Edellä esitetyn perusteella ekososiaalisen sivistyksen arvoiksi on tunnistettavissa vastuullisuus, kohtuullisuus ja ihmistenvälisyys. Ekososiaaliseen sivistykseen kasvettaessa on pohjimmiltaan kyse sellaisten ihmisen vapauksien ja vastuiden ymmärtämisestä, jotka perustuvat riippuvuuteen luonnosta ja toisista ihmisistä. Perimmäisenä inhimillisen kasvun tavoitteena - joka koskee kaikkia ihmisiä ja instituutioita - on sellainen sivistys, joka vahvistaa luottamusta tulevaisuuteen.

\section{EKOSOSIAALISTA SIVISTYSTÄ EDISTÄVÄ INHIMILLINEN KASVU JA OPPIMINEN}

\section{Vastuullisuus}

Yhteiskunnan myönteisen kehityksen syvintä olemusta ilmentää vauraan ja vähäosaisen kansalaisen lähentyminen. Pienten tuloerojen ja hyvinvoinnin välillä on vahva positiivinen korrelaatio, joka kyseenalaistaa uusliberaalia ajatusta siitä, että lähinnä kilpailu ja voittajien palkitseminen tuottaa yhteiskunnallista hyvää (Wilkinson \& Picket 2011). Sen sijaan suuret tuloerot uhkaavat mitätöidä satojen miljoonien ihmisten lahjakkuutta ja työtä (Fuentes-Nieva \& Galasso 2014). Polarisoitumisen välttäminen ei ole mahdollista, ellei kansalaisilla ole taitoja asettua toisten asemaan.

Moraalisen mielikuvituksen kehittyminen auttaa kokemaan maailmaa myös muiden näkökulmista ja herättelee eettistä huolenpitoa. Ekologinen ja sosiaalinen vastuu korreloivat positiivisesti, mikä auttaa huolenpidon piirin laajentamisessa (Uitto \& Saloranta 2012). Ihminen, joka ottaa vastuuta toisesta ihmisestä, ottaa todennäköisesti vastuuta myös luonnosta - ja päinvastoin. Kasvattajan näkökulmasta riittää siis, että onnistuu herättelemään vastuullisuutta joko ihmisten välille tai ihmisen ja luonnon välille. (Taulukko 1.)

Huolenpito perustuu myötätuntoisuuteen. Huolenpidon piiriksi ei riitä pelkästään oma lähiyhteisö, sillä olemme väistämättä maailmankansalaisia. Globaali talous yhdistää esimerkiksi suomalaisen kaunista ja käytännöllistä vaatetta tarvitsevan kuluttajan ja intialaisen perheen, joka tarvitsee rahaa tyttöjensä koulumaksuihin. Liian usein tämä yhdistäminen ei onnistu ihmisoikeuksia kunnioittavalla tavalla (Coninck ym. 2011).

Nykyihmisen huolenpidon piiriin tulee sisällyttää myös tulevat sukupolvet. Olisi moraalitonta jättää lapsemme ja tulevat sukupolvet maksamaan ekologista, sosiaalista ja taloudellista velkaamme, joka on heille liian suuri (OECD 2012). Jos esimerkiksi ilmastonmuutoksen vastaisia toimia vielä siirretään vuoteen 2020, lisääntyvät kustannukset 50-700 prosenttia (Luderer ym. 2012). Kestävän kehityksen idea kiteytyy sellaiseen ihmisen toimintaan, jonka vaikutukset eivät ole uhka inhimillisen elämän pysyvyydelle (Jonas 1984, 43).

Vastuullinen maailmasuhde ilmenee siten, että ihminen on vapaa hyödyntämään luonnonvaroja, mutta velvollinen huolehtimaan materian kierrosta siten, että tuleville sukupolville jää samanveroiset tai paremmat toimintamahdollisuudet kuin meille. Niin ikään yrityksellä on oikeus tuottaa voittoa omistajilleen palkkioksi panoksestaan, mutta samalla velvollisuus toimia sen yhteiskunnan parhaaksi, jossa se vaikuttaa ja jonka tarjoamaa työvoimaa, infrastruktuuria ja luonnonvaroja se hyödyntää.

\section{Kohtuullisuus}

Kohtuullisuus kiteytyy kysymykseen siitä, minkä verran on riittävästi. Luonnonvarojen säästeliäs ja viisas käyttö ja jakaminen ovat rauhantyötä. Jos siinä ei onnistuta, uhkaavat geopoliittiset jännitteet ja niukkuudesta johtuvat konfliktit (Rees 2014, 194-195). Maailman vauraan vähemmistön kulutus vastaa yli 80 prosenttia luonnonvarojen käytöstä ja saastumisesta (Munasinghe 2014, 260). Suhteellisen pienet- 


\section{Minä — Perhe — Ystävät ja sukulaiset — Suomalaiset ihmiset — Länsimaalaiset ihmiset}

Kaikki ihmiset — Ihmiset ja eläimet — Ihmiset, eläimet ja kasvit _ Ekosysteemit _ Maapallo

Taulukko 1. Vastuullinen maailmasuhde kehittyy eettistä huolenpidon piiriä laajentamalla (Salonen 2013a, 2050).

kin muutokset vauraissa maissa vähentävät tehokkaasti luonnonvarojen käyttöä, hillitsevät ilmastonmuutosta ja vapauttavat voimavaroja köyhimpien ihmisten elämänlaadun parantamiseen.

Materiaalisen ylivaurauden tavoittelu tuottaa stressiä, kiirettä, masentuneisuutta, yksinäisyyttä ja epäekologista käyttäytymistä (Bartolini 2014; Jackson 2011; Kasser 2011). Ihmiset, jotka priorisoivat vahvasti materiaalisia elämänpäämääriä ovat tyytymättömiä elämäänsä ja heillä on vähän myönteisiä tunteita (Kasser 2014). Koetun hyvinvoinnin jäljille päästään kiinnittämällä huomiota ymmärretyksi tulemiseen ja itsensä toteuttamiseen (Costanza 2014, 76). Tietoisuustaitojen omaksuminen auttaa hallitsemaan mielen assosiaatiovirtaa. Ajatusten keskittäminen valittuun kohteeseen tuottaa tyydytystä ja mielenrauhaa. Se voi auttaa kasvamaan kuluttajasta kohti täydempää ihmisyyttä (Pulkki 2014).

Suomessa 37 prosenttia nuorista on vähentänyt kuluttamistaan (Komonen \& Leminen 2014). He ovat ehkä oivaltaneet, että lisääntyneet kulutusmahdollisuudet usein vähentävät kykyä nauttia rahan avulla saavutettavista asioista (Quoidbach ym. 2010). Koetun hyvinvoinnin näkökulmasta havahduttavaa on se, että Itä-Afrikan masait arvioivat tyytyväisyytensä elämäänsä yhtä hyväksi kuin 400 vaurainta yhdysvaltalaista (Diener \& Seligman 2004). Masait asuvat lehmänlannasta, mullasta ja ohuista puunrungoista tehdyissä asunnoissa. Vahvaan kulttuuriperinteeseen perustuva paimentolaisuus on kuitenkin näihin päiviin saakka turvannut heidän toimeentulonsa ja vahvistanut riittävyyden kokemuksia.
Keskeiseksi inhimillistä kasvua ja oppimista määrittäväksi kysymykseksi muodostuu se, mitä tarvitaan enemmän ja mitä vähemmän hyvään elämään (Sachs \& Santarius 2007, 161). Kohtuullisuutta ja riittävyyttä tavoiteltaessa oleellista on erottaa tarpeet ja halut toisistaan. Välttämättömät tarpeet viittaavat universaaleihin hyvän elämän elementteihin, jotka ovat kaikille ihmisille samoja. Sen sijaan haluihin perustuvat valinnat voidaan eettisesti kyseenalaistaa (Di Giulio ym. 2014, 51; Helne ym. 2014, 141-149). Materiaalisen mielihyväkulutuksen väheneminen on suuri haaste (Pulkki 2014). Ekososiaaliseen sivistykseen liittyvä vapaus voi olla vapautta kasvun pakosta, joka pitää ihmistä tyytymättömyyden ja riittämättömyyden tilassa (Pulkki 2010, 51).

Pohjimmiltaan ihminen haluaa tulla nähdyksi ja kuulluksi sekä saada tunnustusta omasta arvokkuudestaan. Nämä tekijät tukevat itseluottamusta ja kokemusta elämän merkityksellisyydestä. Arvottomaksi itsensä kokevan ihmisen on vaikeaa arvostaa toisia ihmisiä ja kokea vastuuta yhteisestä tulevaisuudesta (Värri 2011,36). Oman arvon kokemusta voivat lisätä aikaansaavuus, ilmaisumahdollisuudet, tiedon saanti, uppoutuminen tekemiseen, kyky olla läsnä ja omien mahdollisuuksien tunnistaminen. Sosiaalisia, henkisiä ja kulttuurisia tarpeita voidaan tyydyttää rajattomasti.

\section{Ihmistenvälisyys}

Ihmistenvälisyydessä on kyse mahdollisuudesta osallistua erilaisiin yhteisöihin ja mahdollisuus olla niissä hyväksytty sellaisena kuin on. Itsekeskeisyys 
"sekä latistaa että kaventaa elämäämme, köyhentää sen merkityssisältöä ja tekee meidät piittaamattomiksi muista ihmisistä ja yhteiskunnasta" (Taylor 1995, 36). Pohjimmiltaan yksittäisen ihmisen ja yhteiskunnan hyöty palautuu samaan asiaan, sillä ihmisten välinen koheesio rikkoutuu jos yksilöt yrittävät riistää tätä tiettyä asiaa itselleen (Pulkki 2010, 48).

Koetun hyvinvoinnin kannalta ihmissuhteet ovat merkittävässä asemassa (Diener \& Seligman 2004; Ryff 1989). Ihmiset, jotka kokevat vahvaa yhteenkuuluvuutta, ovat tyytyväisempiä elämäänsä kuin ne, joilla tätä tunnetta ei ole (Helliwell 2011). Ensimmäinen tehdastyöläisten sukupolvi halusi mieluummin tehdä lyhyttä työpäivää kuin saada enemmän palkkaa. Rahalla saatavat hyödyt eivät olleet heille niin tärkeitä kuin ajan viettäminen oman perheen ja yhteisön kanssa (Stearns 2001, 34-35).

Yhteenkuuluvuuden ja ekologisuuden välillä on silta, sillä ystävyyden ja osallisuuden toteutuessa omistamisen merkitys vähenee. Kulutuksen painopiste siirtyy omistamisesta palvelujen käyttöön. Sen sijaan markkinaehtoinen ajattelu lisää kilpailullisuutta, vähentää yhteisöllisyyttä ja pitää yllä jatkuvaa riittämättömyyden tuntua (Marglin 2008). Siirtyminen materiaalisista elämäntavoista aineettomimpiin on keskeinen tekijä teollistuneiden yhteiskuntien aine- ja energiaintensiivisyyden vähentämisessä. Oman elämän tekijäksi tuleminen on tässä muutoksessa keskeisessä roolissa.

Solidaarisuus lisää koettua hyvinvointia. Abraham Maslowin $(1960,118)$ mukaan henkisen kasvun huipentuma on täysi ihmisyys, jolle on tyypillistä liittyminen muihin ihmisiin ja altruismi. Ihmiset kokevat itsensä onnellisiksi elämällä muiden ihmisten kanssa ja muita ihmisiä varten (Dunn ym. 2008; Helliwell 2014, 81). Esimerkiksi lapset pyrkivät käyttäytymään altruistisesti siitä huolimatta, että itsekkäitä käyttäytymismuotoja palkitaan (Warneken \& Tomasello 2009). He myös kokevat itsensä onnellisemmiksi antaessaan kuin vastaanottaessaan (Aknin ym. 2012). Kasvattajan näkökulmasta hy- vään tukeminen on avaintekijä. Sekä yhteiskunnan että yksilön hyvinvointi hyötyy altruistisista päämääristä, jotka auttavat ihmisiä hillitsemään keskinäisestä kilpailua ja ahneutta voimistamalla ihmisten välistä myötätuntoa ja yhdessä toimimista (Jackson 2011; Kahneman ym. 2006; Max-Neef 2010,200-204).

Täyteen ihmisyyteen kasvaminen helpottuu, jos on olemassa yhteisöllisiä tiloja ja paikkoja, joissa ihminen voi oppia ja kehittyä vastavuoroisessa, tunnustusta antavassa ja vapaassa ilmapiirissä (Värri 2011,36). Nykyhetkeen liittyvän kokemuksen täyteys on ensiarvoista. Tieteet ja taiteet tuottavat välineitä ja havaintoja käsitysten korjaamiseen sekä kokemusten ja tunteiden syventämiseen. Niiden avustavaa voimaa tarvitaan siirryttäessä materiaalikeskeisestä kulutuskulttuurista kestävämpään kehitykseen ja täydempään ihmisyyteen (Bardy 2012b). Koettu hyvinvointi parantuu, jos arkiset kokemukset muuttuvat merkityksiltään aikaisempaa rikkaammiksi (Alhanen 2013, 149-150). Myönteiset elämää kannattelevat kokemukset liittyvät useammin toisiin ihmisiin kuin materiaalisiin asioihin.

\section{HYVÄ ELÄMÄ YHDEN MAAPALLON RAJOISSA}

Ekososiaalinen sivistys on vastaus sekä planetaaristen rajojen ylittymiseen että ihmisten väliseen eriarvoistumiseen. Arkisten valintojen vertailu, kasvatuspäämäärien asettaminen ja poliittinen päätöksenteko on vaikeaa, mikäli ekologisten, sosiaalisten ja taloudellisten kehitysintressien välistä hierarkiaa ei tunnisteta eikä tunnusteta. Edellytyksenä on asioiden ja ilmiöiden hahmottaminen toisiinsa kytkeytyvänä systeemisenä kokonaisuutena. Valinnat yhdessä kohdassa vaikuttavat valintoihin toisissa elämänpiireissä. Esimerkiksi pitkät työpäivät voivat lisätä tuloja ja tuottaa henkistä tyydytystä. Toisaalta ne vähentävät käytettävää aikaa lasten tai muiden läheisten kanssa. Työnteon ja aineellisen kulutuksen vähentäminen puolestaan antaa mahdollisuuksia lisätä aikaa läheisten kanssa tai kansalaistoiminnassa, ja vähentää stressiperäisiä ongelmia. 
Kuvio 1. Luonnonvarojen hyödyntäminen, saastuminen ja päästöt tasa-arvoiseen yhden planeetan politiikkaan pyrittäessä.

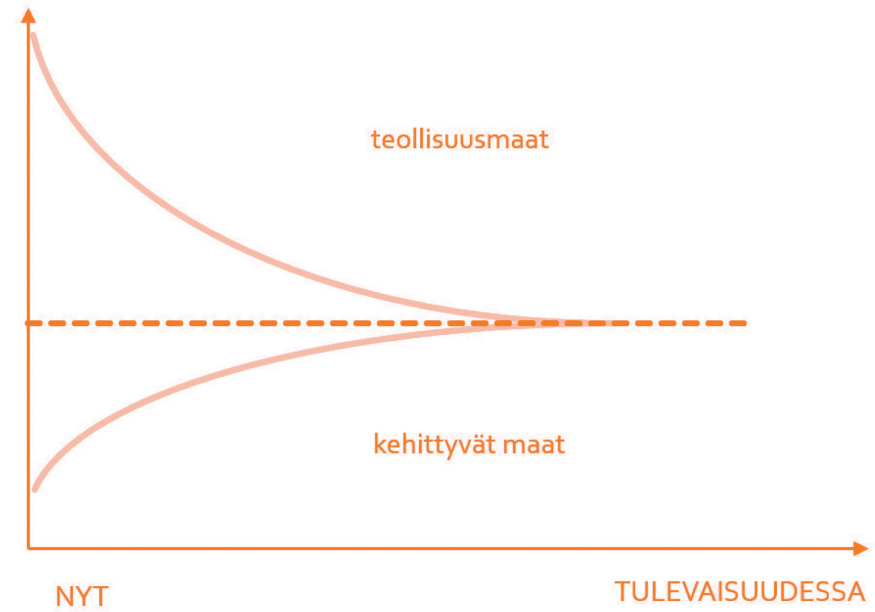

Kohtuullisuuden ja riittävyyden näkökulmasta tarkasteltuna nopeaa määrälliseen lisäämiseen perustuvaa talouskasvua tarvitaan siellä, missä ihmisten perustarpeiden tyydyttäminen ei vielä ole mahdollista (kuvio 1). Sen sijaan teollistuneissa maissa ekososiaalinen sivistyskäsitys siirtää koetun hyvinvoinnin tavoittelun painopistettä laadulliseen parantamiseen. Laadullisen parantamisen paradigmaan siirtyminen on mahdollista perustarpeiden ollessa jo tyydytettyjä.

Palvelutalous, kiertotalous, paikallistalous ja reaalihintatalous ovat ekososiaalisen sivistyksen yhteiskunnallisia ilmentymiä. Ne voivat lisätä luottamusta tulevaisuuteen vähentämällä materian ja energian tarvetta sekä lisäämällä läpinäkyvyyttä. Monet tarpeet eivät liity omistamiseen vaan palveluun. Ensisijainen tarpeemme on useimmiten reikä seinään silloin tällöin, eikä porakoneen omistaminen. Tarvitsemme liikkumismahdollisuuksia enemmän kuin autoa. Kiertotalous on ratkaisu luonnonvarojen riittävyyteen, sillä kaikki ihmisen tarvitsema materiaalinen hyvä otetaan luonnosta ja palautetaan luontoon. Talouden paikallistuminen lisää läpinäkyvyyttä, vakautta ja riippumattomuutta. Jos raha kiertää paikallistaloudessa useita kertoja poistumatta siitä, on seurauksena talousbuumi
(Max-Neef 2010, 204). Reaalihintataloudessa tuotteiden ja palvelujen hinnat sisältävät niiden tuottamisesta ja kuluttamisesta johtuvien ulkoisvaikutusten kustannukset. Tällöin kuluttajan rationaaliset valinnat ovat helpompia ja markkinat ohjautuvat ihmisen ja luonnon kannalta parhaaseen suuntaan (Parry ym. 2014).

Altruististen ja egoististen tavoitteiden samanaikainen toteutuminen antaa mahdollisuuden siirtyä tulevaisuuteen liittyvien ongelmien ratkaisemisessa kohti tasa-arvoa - ja ehkäpä uhrautumispuheesta onnellisuuspuheeseen. Työn jakaminen voi lisätä itsensä toteuttamisen mahdollisuuksia samalla, kun se luo uuden työpaikan sitä tarvitsevalle (Rees 2014, 197-198). Terveelliset elämäntavat säästävät yhteiskunnan voimavaroja ja parantavat henkilökohtaista elämänlaatua. Esimerkiksi paikallisesti tuotettu kasvispainotteinen luomuruoka on yhä useammalle täydellinen vaihtoehto. Käytetty raha jää hyödyttämään paikallista yhteisöä, ravinto edistää terveyttä ja eläinten hyvinvoinnista on huolehdittu. Lisäksi se ylläpitää luonnon monimuotoisuutta ja tukee globaalin ruokaturvan toteutumista (Salonen 2013b). Kotitalouden energian lähteen vaihtaminen likaisesta puhtaaseen vapauttaa osaratkaisujen pohtimisesta ja poissulkee tapahtu- 
maketjun, joka on yhteydessä peruuttamattomiin muutoksiin planeetallamme. Tämä voi olla vahva ja merkityksellinen kokemus, sillä fossiilisilla energianlähteillä tuotetun sähkön, lämmön ja liike-energian käyttö on yhteydessä sellaisiin elämän edellytyksiä peruuttamattomasti kaventaviin muutoksiin, jotka viittaavat sisällöllisesti ihmisoikeusloukkauksiin.

Ekososiaalinen sivistys ilmenee vapauden ja vastuun tasapainona ihmisen ajattelussa ja toiminnassa rajallisella maapallolla. Uudenlainen sivistys pyrkii ennen kaikkea siihen, että 2000-luvun alkupuolen saavutukseksi kirjataan siirtyminen hyvän elämän tavoittelussa materiaalisista elämäntavoista henkisiin. Ekososiaalisesti sivistynyt ihminen tunnistaa, minkä verran materiaalista hyvää on riittävästi. Hän tiedostaa, että aineeton pääoma voi kasvaa rajattomasti, mutta materiaaliselle kulutukselle maapallo asettaa rajat. Yhteiskunnallinen muutosprosessi tähän suuntaan on jo käynnistynyt. Sen on saanut aikaan ihmisten arvoissa tapahtunut muutos materian määrän korostamisesta elämän laatua painottaviin arvoihin (Stiglitz ym. 2009, 63). Elämän laatua painottavat postmateriaaliset arvot yleistyvät etenkin Suomen kaltaisissa maissa, joissa nykyinen sukupolvi varttuu sellaisissa olosuhteissa, joissa perustarpeiden tyydyttämiseen liittyviä asioita voidaan pitää itsestään selvyyksinä (Inglehart 2008, 145).

Suuretkin yhteiskunnalliset muutokset ovat mahdollisia. Suomalaisten eliniänodote on lyhyehkössä ajassa lähes kaksinkertaistunut. On luotu kattava koulutus- ja terveydenhoitojärjestelmä. Globaali kaikkea elämää uhannut otsonikerroksen repeytymisen laajentuminenkin on jo pysäytetty. Ratkaisun puolelle asettuminen omien arkisten valintojen kautta voi avata uuden merkitysnäköalan omaan elämään toisin kuin ongelmien vahvistajana oleminen. Systeemiajattelun mukaisesti jokea ei synny ilman metsään satavia yksittäisiä pisaroita. Parhaimmillaan ratkaisun puolelle asettuvien ihmisten yhteistoiminta voi johtaa huomattavaan muutosten jokeen, joka aluksi tuntui mahdottomalta.
Mahdollisuuksien voimaa kuvaa se, että vuoden 2008 talouskriisin ratkaisemiseen varatuilla rahoilla voitaisiin nostaa äärimmäisestä köyhyydestä miljardi ihmistä 566 vuoden ajaksi (Max-Neef 2010, 200), tai jo yhden päivän Yhdysvaltojen puolustusministeriön kuluilla saisi kaikille Afrikan mantereen asukkaille malariaverkot viideksi vuodeksi (Sachs 2008, 275). Jos haluamme, voimme myös hillitä ilmastonmuutosta siten, ettei ilmasto lämpene esiteolliseen aikaan verrattuna enempää kuin kaksi astetta vuoteen 2100 mennessä. Ilmastonmuutoksen hillinnän kustannukset olisivat 3-5 prosenttia maailman bruttokansantuotteesta (Edenhofer ym. 2014; Randers \& Gilding 2010; Randers 2012). Korjaustoimenpide palauttaisi luottamuksen talouteen ja toivon ihmiskunnalle. Kestävä maailma on mahdollinen, mutta se edellyttää ekososiaalista sivistymistä.

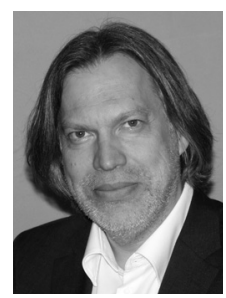

Arto O. Salonen

KT, kasvatustieteen dosentti Metropolia Ammattikorkeakoulu

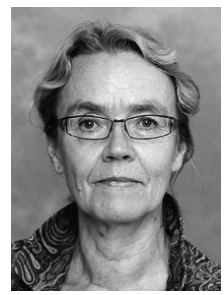

Marjatta Bardy

$K T$, sosiaalipolitiikan dosentti tutkimusprofessori emerita 


\section{LÄHTEET}

Adger, N. (2000). Social and ecological resilience. Progress in Human Geography, 24(3), 347-364.

Aknin, L., Hamlin, J., \& Dunn, E. (2012). Giving leads to happiness in young children. PLoS ONE 7(6), e39211.

Alhanen, K. (2013). John Deweyn kokemusfilosofia. Helsinki: Gaudeamus.

Bardy, M. \& Parrukoski, S. (2010) (toim.) Hyvinvointi ilmastonmuutoksen oloissa? Helsinki: THL, Yliopistopaino.

Bardy, M. (2012a). Kestävän kehityksen vaikuttavuuden parantamisesta. Teoksessa Sakari Hänninen \& Maijaliisa Junnila (toim.) Vaikuttavatko politiikkatoimet? Helsinki: THL, 113-121.

Bardy, M. (2012b). Taide, tiede ja myötätunto. Synteesi, 29-47.

Bardy, M. (2015). Ilmastokriisi ja yhteiskunnallinen neuvokkuus. Yhteiskuntapolitiikka 1/2015, 83-89.

Bartolini, S. (2014). Buying alone: how the decreasing American happiness turned into the current economic crisis. Teoksessa Timo Hämäläinen \& Juliet Michaelson (toim.) Well-being and Beyond - Broadening the Public and Policy Discourse. Northhampton: Edward Elgar Publishing, 144-181.

Benzer, M. (2011). The Sociology of Theodor Adorno. Cambridge: Cambridge University Press.

Braconier, H., Nicoletti, G. \& Westmore, B. (2014). Policy challenges for the next 50 years. OECD Economic Policy Papers. OECD Publishing. Luettavissa http:// www.oecd.org/economy/Policy-challenges-for-thenext-fifty-years.pdf. Luettu 28.1.2015.

Bureau of International Labor Affairs (2014). U.S. Department of Labor's List of Goods Produced by Child Labor or Forced Labor. Trafficking Victims Protection Reauthorization Act of 2005. Bureau of International Labor Affairs, Washington: U.S. Department of Labor. Luettavissa: http://www.dol. gov/ilab/reports/child-labor/list-of-goods. Luettu 27.1.2015.

Caldeira, K., \& Davies, S. (2010). Consumption-based accounting of $\mathrm{CO} 2$ emissions. PNAS 107(12), 56875692
Coninck, N. Theuws, M. \& Overeem, P. (2011). Captured by Cotton. Exploited Dalit girls produce garments in India for European and US markets. Amsterdam: SOMO - Centre for Research on Multinational Corporations. Luettavissa: www.indianet.nl/pdf/ CapturedByCotton.pdf.

Costanza, R. (2014). A Virtual Visit to a Sustainable 2050. Teoksessa Robert Costanza ja Ida Kubiszewski (toim.) Creating a Sustainable and Desirable Future. London: World Scientific, 73-84.

Daly, H. (2010). From a Failed-Growth Economy to a Steady-State Economy. Solutions 1(2), 37-43.

Di Giulio, A., Fischer, D., Schäfer, M., \& Blätter-Mink, B. (2014). Conceptualizing sustainable consumption: toward ad integrative framework. Sustainability: Science, Practice, \& Policy 10(1), 45-61.

Diener, E. \& Seligman, M. (2004). Beyond Money. Psychological Science in the Public Interest 5(1), 1-31.

Dittrich, M., Giljum, S., Lutter, S., Polzin, C. (2012). Green economies around the world? Implications of resource use for development and the environment. Vienna: SERI. Luettavissa http://seri.at/greeneconomies

Dunn, E., Aknin, L., \& Norton, M. (2008). Spending Money on Others Promotes Happiness. Science 319(5870), 1687-1688.

Edenhofer, O., R. Pichs-Madruga, Y. Sokona, E. Farahani, S. Kadner, K. Seyboth, A. Adler, I. Baum, S. Brunner, P. Eickemeier, B. Kriemann, J. Savolainen, S. Schlömer, C. von Stechow, T. Zwickel ja J.C. Minx (2014). Mitigation of Climate Change. Contribution of Working Group III to the Fifth Assessment Report of the Intergovernmental Panel on Climate Change. Cambridge: Cambridge University Press.

Ehrlich, P. ja Ehrlich, A. (2013). Can a collapse of global civilization be avoided? Proceeding of the Royal Society 280(1754), 1-10.

Ehrlich, P., Kareiva, P., \& Daily, G. (2012). Securing natural capital and expanding equity to rescale civilization. Nature 486, 68-73. 
Eskelinen, T. (2011). Kehityksen loppu. Helsinki: Into.

Executive Office of the President of the United States (2014). The cost of delaying action to stem climate change. Luettavissa www.whitehouse.gov/sites/ default/files/docs/the_cost_of_delaying_action_to_ stem_climate_change.pdf.

Fuentes-Nieva, R. \& Galasso, N. (2014). Working for the few. Political capture and economic inequality. Oxford: Oxfam International.

Helliwell, J. \& Barrington-Leigh, C. (2011). How much is social capital worth? Teoksessa J. Jetten, C. Haslam, \& S. Haslam (toim.), The Social Cure. London: Psychology Press, 55-57.

Helliwell, J. (2014). Social norms, happiness, and the environment: closing the circle. Sustainability: Science, Practice, \& Policy 10(1), 78-84.

Helne, T. \& Hirvilammi, T. \& Laatu, M. (2012) Sosiaalipolitiikka rajallisella maapallolla. Helsinki: Kela.

Helne, T. \& Hirvilammi, T. \& Alhanen, K. (2014) (toim.) Kriisi-istunto: dialogi ekologiseen hyvinvointivaltioon siirtymisestä. Helsinki: Kela.

Hirvilammi, T. \& Helne, T. (2014). Changing Paradigms: A Sketch for Sustainable Wellbeing and Ecosocial Policy. Sustainability 6: 2160-2175.

Inglehart, R. (2008). Changing Values among Western Publics from 1970 to 2006. West European Politics, 31(1-2), 130-146.

Jackson, T. (2011). Hyvinvointia ilman kasvua - Rajallisen planeetan taloustiede. Suom. Jyri Raivio. Helsinki: HS kirjat.

Jonas, H. (1984). The Imperative of Responsibility. Chicago: University of Chicago Press.

Joughin, I., Smith, B., \& Medley, B. (2014). Marine Ice Sheet Collapse Potentially Underway for the Thwaites Glacier Basin, West Antarctica. Science 344(6185), 735-738.

Kahneman, D., Krueger, A., Schkade, D., Schwarz, N., \& Stone, A. (2006). Would you be happier if you were richer? A focusing illusion. Science 312(5782), 1908-1910.

Kasser, T. (2011). Ecological challenges, materialistic values, and social change. Teoksessa R. BiswasDiener (toim.) Positive Psychology as Social Change. Dordrecht: Springer, 89-108.

Kasser, T. (2014). A Values-Based Se of Solutions for the Next Generation. Teoksessa Robert Costanza and Ida Kubiszewski (toim.). Creating a Sustainable and Desirable Future. London: World Scientific, $331-340$.
Keskuskauppakamari (2012). Sääntely selättää Suomen: Viisi vaarallista hanketta. Lehdistötiedote 19.10.2012. http://news.cision.com/fi/keskuskauppakamari/r/ saantely-selattaa-suomen--viisi-vaarallistahanketta,c9333965. Luettu 15.8.2014

Kokko, H. (2010). Sivistyksen varhaista käsitehistoriaa. Kasvatus \& Aika 4(4), 7-23.

Komonen, P. \& Leminen, E (2014). Kansallinen nuorisotutkimus - uusi kuluttaja. Helsinki: 15/30 Research Oy.

Luderer, G., Bosetti, V., Jakob, M., Leimbach, M., Steckel, J., Waisman, H. ja Edenhofer, O. (2012). The Economics of Decarbonizing the Energy System - Results and Insights from the RECIPE Model Intercomparison. Climatic Change 114(1), 9-37.

Marglin, S. (2008). The Dismal Science. How Thinking Like an Economist Undermines Community. London: Harward University.

Maslow, A. (1960). Toward a Psychology of Being. Blacksburg: Wilder Publications.

Max-Neef, M. (2010). The World on a Collision Course and the Need for a New Economy. Ambio 39(3). 200-210.

Miles, I., Keenan, M. \& Kaivo-Oja, J. (2003). Handbook of Knowledge Society Foresight. European Foundation for the improvement of Living and Working Conditions 2003. Luettavissa: http:// eurofound.europa.eu/sites/default/files/ef_files/ pubdocs/2003/50/en/1/ef0350en.pdf. Luettu 28.1.2015.

Munasinghe, M. (2014). Millenium Consuption Goals MCGs. at Rio+20: A Practical Step Toward Global Sustainability. Teoksessa Robert Costanza and Ida Kubiszewski (toim.) Creating a Sustainable and Desirable Future. London: World Scientific, 255-262.

Nikula, J. (2012). Suomen vesijalanjälki: Globaali kuva suomalaisten vedenkulutuksesta. Helsinki: WWF Suomi.

Nussbaum, M. (2011). Talouskasvua tärkeämpää. Suom. Timo Soukola. Helsinki: Gaudeamus.

OECD (2012). OECD Environmental Outlook to 2050: The Consequences of Inaction. OECD Publishing.

Ojanen, E. (2008). Sivistyksen filosofia. Helsinki: Kirjapaja.

Parry I., Heine, D., Lis, E., \& Li, S. (2014). Getting Energy Prices Right: From Principle to Practice. Washington: International Monetary Fund.

Pulkki, J. (2010). Voitonhimon ongelma. Tiedepolitiikka 4/2010, 39-52. 
Pulkki, J. (2014) Voiko kontemplatiivinen pedagogiikka haastaa konsumerismin? Aikuiskasvatus 34(1), 4-16.

Quoidbach, J., Dunn, E., Petrides, K.V., \& Mikolajczak, M. 2010. Money Giveth, Money Taketh Away: The Dual Effect of Wealth on Happiness. Psychological Science 21(6), 759-763.

Randers, J. \& Gilding, P. (2010). The one degree war plan. Journal of Social Responsibility 1(1), 170-188.

Randers, J. (2012). 2052 - A global forecast for the next forty years. Vermont: Chelsea Green Publishing.

Reardon, S. (2012). Will we ever be able to buy a fairtrade smartphone? New Scientist 2860, 18.

Rees, W. (2014). The Way Forward: Survival 2100. Teoksessa Robert Costanza and Ida Kubiszewski (toim.). Creating a Sustainable and Desirable Future. London: World Scientific, 191-200.

Rignot, E., Mouginot, J., Morlighem, M., Seroussi, H. ja Scheuchl, B. 2014. Widespread, Rapid Grounding Line Retreat of Pine Island, Thwaites, Smith, ja Kohler Glaciers, West Antarctica, from 1992 to 2011. Geophysical Research Letters 41(10), 3502-3509.

Ryff, C. (1989). Happiness is everything, or is it? Explorations on the meaning of psychological wellbeing. Journal of Personality and Social Psychology, 57(6), 1069-1081.

Sachs, J. (2008). Common Wealth. Economics for a Crowded Planet. New York: Penguin Press.

Sachs, W. \& Santarius T. (toim.) (2007). Fair Future. Resource conflicts, security \& global justice. London: Zed Books.

Salonen, A. (2013a). Responsible Consumption. Teoksessa Idowu, S., Capaldi, N., Zu, L., Das Gupta, A. (toim.). Encyclopedia of Corporate Social Responsibility. Berlin: Springer, 2048-2055.

Salonen, A. (2013b). Kasvisruokavalion mahdollisuudet kestäviä elämäntapoja tavoiteltaessa. Janus 21(1), 22-40.

Salonen, A. (2014). Ekososiaalinen hyvinvointiparadigma - yhteiskunnallisen ajattelun ja toiminnan uusi suunta täyttyvällä maapallolla. Teoksessa Juha Hämäläinen (toim.) Sosiaalipedagoginen aikakauskirja 2014. Suomen sosiaalipedagoginen seura.

Salonen, A. (2015). An Ecosocial Approach in Education. Teoksessa Rolf Jucker ja Reiner Mathar (toim.) Schooling for Sustainable Development: Concepts, Policies and Educational Experiences. BerlinHeidelberg: Springer.
Sen, A. (2009). The idea of justice. Cambridge: Harvard University

Stearns, P. (2001). Consumerism in World History: The Global Transformation of Desire. New York: Routledge.

Stiglitz, J., Sen A., Fitoussi, J-P. (2009). The Measurement of Economic Performance and Social Progress Revisited. Commission on the Measurement of Economic Performance and Social Progress.

Taylor, C. (1995). Autenttisuuden etiikka. Alkuperäisteos Ethics of Authenticity. Suom. Timo Soukola. Helsinki: Gaudeamus.

The Royal Society (2012). People and the planet. The Royal Society. Science Policy Centre report 01/12. London: The Royal Society.

Uitto, A. \& Saloranta S. (2012). Yhdeksännen luokan oppilaat kestävän kehityksen kasvatuksen kokijoina ja toimijoina. Teoksessa Helmi Risku-Norja, Eila Jeronen, Sirpa Kurppa, Minna Mikkola ja Anna Uitto (toim.) Ruoka - oppimisen edellytys ja opetuksen voimavara. Mikkeli: Ruralia instituutti/Helsingin yliopisto, 48-58.

Vaarama, M., Moisio, P. Karvonen, S. (2010) Johdanto. Teoksessa M. Vaarama ym. (toim.) Suomalaisten hyvinvointi 2010. Helsinki: THL.

Warneken, F. \& Tomasello, M. (2009). The roots of human altruism. British Journal of Psychology 100(3), 455-471.

Whiteman, G., Hope, C. \& Wadhams, P. (2013). Vast costs of Arctic change. Nature 499, 401-403.

Wiedmann, T., Schandl, H., Lenzen, M., Moran, D. Suh, S., West, J. \& Kanemoto K. (2013). The material footprint of nations. PNAS. http://www.pnas.org/ content/early/2013/08/28/1220362110.full.pdf+html. Luettu 10.8.2014.

Wilkinson, R. \& Pickett, K. (2011). Tasa-arvo ja hyvinvointi: Miksi pienet tuloerot koituvat kaikkien hyväksi. Suom. Markus Myllyoja. Helsinki: HS kirjat.

Värri, V-M. (2011) Vastuu ihmisen mittana. Kasvatusteoreettisia ja filosofisia näköaloja ekologiselle sivistysprojektille. Tiedepolitiikka 4. 27-35. 